\title{
AN INVESTIGATION OF THE ESSENTIAL OIL OF THE ROOTS
}

\section{OF Paeonia anomala}

\author{
G. I. Kalinkina, A. D. Dembitskii, E. Sh. Bergaliev, \\ and L. A. Zarubina
}

UDC 547.913

Paeonia anomala L. - Ural peony - is a perennial herbaceous plant of the Paeoniaceae family. The whole plant contains essential oils. The essential oil from the roots of the Ural peony gathered in Western Siberia has shown a high antimicrobial activity [1], which has served as a basis for the investigation of its chemical composition. The essential oil was obtained from the comminuted roots by steam distillation, by distillation with superheated steam, and by distillation with steam from the previously ground roots. Since the essential oil dissolves in water, it was collected in a receiver containing diethyl ether. After drying with anhydrous sodium sulfate and evaporation of the ether, the essential oil consisted of a yellowish transparent liquid with a sharp odor and a burning taste. The yield was $0.55-1.70 \%$ (depending on the method of isolation). Constants: $\mathrm{d}_{20}{ }^{20} 1.6240 ; \mathrm{n}_{\mathrm{D}}{ }^{20} 1.5355-1.5394$.

Gas-liquid chromatographic analysis of the essential oil showed that, regardless of the method used for its isolation, it consisted essentially of two components and contained no substances of terpene structure. Of the five components present in minor amounts and not in total exceeding one per cent, we isolated substance (I) with $n_{\bar{D}}^{20} 1.5450$, having a smell of almonds. IR spectrum $\left(\mathrm{cm}^{-1}: 703,2603,3026,3061,3090\right.$ (monosubstituted benzene ring), 1665, $2740\left(-\mathrm{C}_{\mathrm{H}}{ }^{\mathrm{O}}\right)$. These characteristics correspond to benzaldehyde. Substance (II) was identified as methyl benzoate: $\mathrm{n}_{\mathrm{D}}{ }^{20} 1.5167$. IR spectrum: 1243,1671 $(-\mathrm{O}-\mathrm{C}=\mathrm{O}), 712,741,1603,3024,3073,3087\left(\mathrm{C}_{6} \mathrm{H}_{5}-\right)$.

The main component of the essential oil was methyl salicylate (III) $\mathrm{n}_{\mathrm{D}}{ }^{20} 1.5360 ; \mathrm{d}_{20}{ }^{20} 1.1610$. IR spectrum, $\mathrm{cm}^{-1}$, $1615\left(\mathrm{C}_{6} \mathrm{H}_{4}-\right), 1250,1678(-\mathrm{O}-\mathrm{C}=\mathrm{O}), 3190(-\mathrm{OH})$. The identification was confirmed by its $\mathrm{PMR}$ spectrum and by the formation of salicylic acid (mp $158-159^{\circ} \mathrm{C}$ ). Substance (IV) was $p$-hydroxybenzaldehyde: $\mathrm{n}_{\mathrm{D}}{ }^{20} 1.5628$. IR spectrum, $\mathrm{cm}^{-1}$ : $1580\left(\mathrm{C}_{6} \mathrm{H}_{4}-\right), 1668,2755(\mathrm{H}-\mathrm{C}=\mathrm{O}), 3150$ ( $-\mathrm{OH}$, broad band).

Thus the esential oil of the roots of the Ural peony contained methyl salicylate $(88 \%), p$-hydroxybenzaldehyde (11\%), benzaldehdye $(0.2 \%)$, and methyl benzoate $(0.1 \%)$, and aiso $\beta$-phenylethyl alcohol $(0.1 \%)$ and thymol $(0.1 \%)$, which were identified with the aid of GLC by the addition of the authentic substances to the essential oil.

The results that we obtained differ to some degree from those in the literature.

GLC was performed on a Chrom-4 instrument with a $3 \mathrm{~mm} \times 0.35 \mathrm{~m}$ column, containing $15 \%$ of PEGA on Celite $545,0.20-0.25 \mathrm{~mm}$; argon, $25 \mathrm{ml} / \mathrm{min}$; programming from 70 to $195^{\circ} \mathrm{C}$ at $2^{\circ} \mathrm{C} / \mathrm{min}$. The substances were isolated on a UKh-2 instrument with a $7 \mathrm{~mm} \times 0.27 \mathrm{~m}$ column, INZ-600 refractory brick modified with polyvinylpyridine, 0.25-0.31 mm; PEG 20.25\%. Temperature $190^{\circ} \mathrm{C}$. IR spectra were taken on a UR-20 spectrometer, and PMR spectra on Tesla $487.80 \mathrm{MHz}$ spectrometer.

\section{REFERENCES}

1. G. I. Kalinkina, L. A. Zarubina, T. P. Berezovskaya, E. A. Serikh, S. E. Dmitruk, and V. N. Tikhonov, A Resourcemanaging and Phytochemical Study of the Flora of the USSR [in Russian], Nauchn. Trudy VNIIF, 29, 89-93 (1991).

2. Plant Resources of the USSR: Flowering Plants, their Chemical Composition and Use. The Paeoniaceae-Thymelaceae Families [in Russian], Nauka, Leningrad (1986), p. 7.

3. E. Gildemeister and F. Hoffmann, Die Ätherischen Öle, Akademie Verlag, Berlin, Vol. 11 (1960), p. 383.

4. Mitsuo Miyazawa, Haruo Maruyama, and Hiromu Kameoka, Agric. Biol. Chem., 48, No. 11, 2847-2849 (1984).

Siberian State Medical Univesity, Tomsk. Institute of Chemical Sciences, Kazakhstan Academy of Sciences, Alma-Ata. Translated from Khimiya Prirodnykh Soedinenii, No. 6, 905-906, November-December, 1993. Original article submitted May 4, 1993. 